\title{
Towards a comparative research agenda on in situ urbanisation and rural governance transformation
}

\begin{abstract}
This article explores how rural settlements urbanise, and how rural governance transforms in the process. The question is motivated by the significant contribution that smaller urban centres are projected to make to the world's future urban growth, the majority of which will occur in the global South. Many smaller centres are emerging through in situ urbanisation, wherein a rural settlement becomes urban. Given the importance of small town growth, the article proposes a comparative research agenda with the aim of exploring and comparing the institutional transformations occurring in 'transitional spaces', the governance complexities these transformations present and the consequences for establishing urban planning systems in historically rural settlements. The agenda is operationalised in sub-Saharan Africa through a case study of Karonga Town, an emerging urban centre in Malawi. The agenda draws on a varied body of case-study research on small town growth and rural transformation in sub-Saharan Africa generally and Malawi specifically. The agenda has the potential to make a significant contribution to the literature seeking to reveal the informality in different governance landscapes and the forms of urbanisation in which these landscapes are embedded in sub-Saharan Africa and beyond.
\end{abstract}

Keywords: governance, urban planning, in situ urbanisation, emerging urban centres, transitional spaces, Malawi, sub-Saharan Africa, global South

\section{Introduction}

This article explores the novel question of how rural settlements become urban, and how rural governance transforms in the process. The question is motivated by the renewed interest in small and intermediate urban centres given the significant contribution they are projected to make to the world's future urban growth, the majority of which is set to occur in the global South (Agergaard et al., 2019). Many of these smaller centres are emerging through in situ urbanisation, wherein a rural settlement becomes a small town (Africapolis, 2009). This form of urbanisation differs from other patterns of urbanisation involving the growth and expansion of existing urban centres, as depicted in the debate on peri-urbanisation (for example, Allen et al., I999; Simon et al., 2004; McGregor et al., 2006). To capture these important differences, the article supports calls for comparative research on diverse forms of urbanisation, with a particular interest in how they challenge existing theories about urban governance (see Auerbach et al., 2018). The aim is to explore and compare the institutional 
transformations occurring in what have been termed 'transitional spaces' (Lazaro et al., 20I9), the governance complexities these transformations present and the consequences for establishing urban planning systems in historically rural settlements.

The agenda is operationalised through a detailed case study of Karonga Town, an emerging urban centre in Malawi. Karonga Town represents a relevant case given its similarities to other emerging urban centres in the region, notably a small and rapidly growing population, location in a rural territory historically dominated by agriculture, a diversifying economy, limited local state presence and the existence of hereditary chiefs. The proposed agenda draws on a varied body of case-study research on small town growth and rural transformation in sub-Saharan Africa generally (in particular, Bryceson, 20II; Lazaro et al., 2019) and Malawi specifically (in particular, Chirwa, 2005; Cammack et al., 2009; Eggen, 201 I), with particular reference to governance transitions. Primary data for the case study come from seventeen semi-structured interviews and numerous informal discussions with key informants (including community members, chiefs and local officials) conducted over a sevenmonth period between February and August 2017. Secondary data (including policy reports, plans and research) were also utilised to ground the study in the regional, national and local context.

The article begins by developing a framework to conceptualise in situ urbanisation and rural governance transformation in the sub-Saharan African context. The following section provides a background account of Malawi's urban transition, with a focus on the changing roles of chiefs in urban and rural governance. The next section explores Karonga Town's urban trajectory, the transformation of its governance structure and the challenges faced by the formal planning system. The article concludes by discussing the key observations followed by the conditions that make them generalisable to other cases, positioning Karonga Town at the forefront of a comparative research agenda on in situ urbanisation and rural governance transformation in Malawi and beyond.

\section{Conceptualising in situ urbanisation and rural governance transformation}

There are great variations in urbanisation dynamics and governance conditions within sub-Saharan Africa that warrant particular attention (Stren and White, I989; Mabogunje, I990; Rakodi, I997; Simon, I997; Pieterse, 2008; 20I i; Goodfellow, 2013; Pieterse and Parnell, 2014; UN-Habitat, 20I4; Smit, 2018). This article is interested in revealing those dynamics and conditions particular to what have been termed 'transitional spaces' (Lazaro et al., 20I9). Two concepts are central here: in situ urbanisation and rural governance transformation. 


\section{In situ urbanisation}

\section{Demographic and spatial processes of urban change}

In situ urbanisation is not a new phenomenon; '[it has been] the primary means of urbanization over several thousand years of human life and urban development' (Africapolis, 2009, 8). In situ urbanisation generally occurs in rural areas with high fertility rates and population densities, leading to the consolidation of traditional village centres (Africapolis, 2009). Two recent studies demonstrate the importance of situ urbanisation and natural increase in sub-Saharan Africa respectively. The first study comes from the Africapolis Project (a geospatial database supported by the Organisation for Economic Co-operation and Development [OECD]), which uses a combination of census data and aerial imagery to generate population estimates of urban centres with more than I0,00o inhabitants (Africapolis, 2009). The study found that 565 new settlements had surpassed Io,ooo inhabitants between 1950 and 2010 in seventeen West African countries, accounting for 34 per cent of the urban population (Moriconi-Ebrard et al., 20I6). The study demonstrates the demographic and spatial transformations occurring at the bottom of the urban hierarchy. The second study by Fox (2017) analysed data from the Demographic and Health Survey (DHS) for twentythree sub-Saharan African countries and found that natural urban growth surpassed natural rural growth in a quarter of the countries sampled. The study demonstrates that rural-urban migration is not necessary for urbanisation to occur.

These trends challenge the tendency in the literature on urbanisation to overstate the importance of the largest cities and rural-urban migration (see Cohen, 2006; Satterthwaite, 2006; 2016; Montgomery, 2008). According to recent census data compiled by the United Nation's Population Division (UNDESA, 2018), there were only two mega cities in sub-Saharan Africa as of 2018: Lagos (Nigeria) and Kinshasa (the Democratic Republic of Congo). By 2030, two other mega cities are projected to emerge: Dar es Salaam (Tanzania) and Luanda (Angola) (UNDESA, 2018). Many of the largest cities are not growing especially fast and are expected to remain few in number relative to small and intermediate urban centres (Cohen, 2006; Satterthwaite, 2007; McGranahan and Satterthwaite, 2014). Studies also show that circular migration trends (rural-urban-rural) have decreased the relative contribution of migration to urbanisation (Beauchemin and Bocquier, 2004; Potts, 2012). Natural increase (when birth rates exceed mortality rates) and reclassification (including rural transformation) appear to be equally (if not more) important to urbanisation in statistical terms (Fox, 2012; 2017; Tacoli et al., 2015).

Despite in situ urbanisation trends, various statistical issues obscure emerging urban centres in census data. These issues involve the absence of universal definitional criteria for determining the threshold when a settlement is large or significant enough (in terms of having the population, density, concentration of non-farm employment or adminis- 
trative status) to be defined as 'urban' (Satterthwaite and Tacoli, 2003). Census data also have large temporal gaps since most censuses are conducted decennially, so it is difficult to capture the periods in which rural centres became urban, including their fastest growth periods (Moriconi-Ebrard et al., 20I6). Meanwhile estimates by Satterthwaite (2016) indicate that nearly 200 million people in sub-Saharan Africa live in urban centres with less than 500,ooo inhabitants, accounting for around half of the urban population, and that these smaller centres are expected to account for a large and typically growing share of the region's urban growth.

\section{Transitional spaces}

This article advances an understanding of in situ urbanisation based on the concept of 'transitional spaces' - i.e. spaces 'where urban and rural living blend and where a clear distinction between urban and rural is difficult to maintain' (Lazaro et al., 20I9, 74). This concept emphasises the historical and contemporary factors propelling the emergence of entirely new urban centres. A variety of factors have been identified, including rapid natural increase and population densification, the nature of agricultural production systems, the existence of local processing facilities, the types of crops being grown, natural resource endowments, mining activities, opportunities to earn income (especially in the non-farm economy) and escape poverty, the existence of financial services (notably microfinance), international trade dynamics, the composition of services, and the quality of local government (Rondinelli, I983; Pedersen, I997; Bryceson, I999; 20I i; Satterthwaite and Tacoli, 2003; Africapolis, 2009; Beegle et al., 2010; Fold and Tacoli, 20ı; Haggblade et al., 20I0; Knudsen, 20I0; Bryceson et al., 20I2; Christiaensen and Todo, 2014; Knudsen and Agergaard, 2015; Larsen and Birch-Thomsen, 2015; Steel et al., 2019).

These factors are contingent and context-dependant. For instance, a detailed case study by Bryceson (2OI I) explored the particular factors propelling the transition of Katoro (Tanzania) from a village to a market town, including its strong market orientation, strategic location on a main road, the existence of surrounding mineral deposits and proximity to international borders. Few other studies have systematically explored how rural settlements become urban (Lazaro et al., (2019) while even fewer have explored how rural governance transforms in the process.

\section{Rural governance transformation}

The concept of governance emerged in the iggos to describe the rise of neoliberalism in the global North and the subsequent involvement of non-state actors (including the private sector and civil society) in decision-making at the national and urban scales (Rhodes, I997; Stoker, I998). Elsewhere in the world, urban governance has become increasingly fragmented in the absence of decentralisation and local state capacity, as 
widely observed in sub-Saharan Africa (UN-Habitat, 20Iob; Smit and Pieterse, 20I4; Smit, 2018). Parnell and Robinson (2012) argue that there are significant limitations in using neoliberalism as a lens to understand governance transformations in parts of the world where the concept has little (if any) relevance. They advocate for an alternative approach to urban theorising grounded in real-world situations.

Following this approach, this section explores contemporary governance transformations unfolding in sub-Saharan African urban centres where a variety of actors have emerged in decision-making, ranging from community groups to religious leaders and faith-based organisations, NGOs, international agencies and the private sector. While a review of these actors is beyond the scope of this article to fully address, and is provided elsewhere (see Smit, 20i8), the focus here is specifically on the role of 'urban chiefs' based on case studies. These studies are unevenly spread geographically, with a particularly strong focus on chiefs in Ghana (see Ubink, 2008a; Yeboah and Obeng-Odoom, 20I0; Yeboah and Shaw, 2013; Boamah, 20I4; Fuseini and Kemp, 2015; Cobbinah and Aboagye, 20ı7; Siiba et al., 2018; Tieleman and Uitermark, 2019 and others). Other case studies have documented the role of customary practices in the delivery of large amounts of urban land in Botswana, Lesotho, Kenya, Nigeria and Uganda (Leduka, 2006; Rakodi, 2006; Nkurunziza, 2007). A recent study by Lazaro et al., (2019) has also addressed the process of establishing formal governance systems in emerging urban centres based on the case of Tanzania. Three themes in this body of research are of interest here: conflict, convergence and transition.

\section{Conflict}

The first theme blames the proliferation of unplanned urban development on the behaviour of chiefs with limited knowledge of formal planning and on ineffective frameworks for formal planning implementation (in particular, Yeboah and ObengOdoom, 20I0; Yeboah and Shaw, 20I3). On the one hand, this theme problematises the large share of land under customary control in urban areas where chiefs continue to serve as trustees, even though many chiefs now accrue most benefits from the sale and development of land, as observed in peri-urban Kumasi (Ubink, 2007; Ubink and Quan, 2008; Cobbinah and Aboagye, 20I7). This theme also problematises chiefs who not only frequently modify existing plans prepared by the planning authority, but who also design their own "improvised "plans" (Yeboah and Shaw, 20I3, 29) in anticipation of urban development. On the other hand, this theme blames human resource shortages, funding shortfalls, ineffective legislation, political interface and weak institutional arrangements for planning failure. This theme is thus primarily concerned with conflict between customary and modern institutions in urban planning and how this conflict can be overcome in practice (see Siiba et al., 20I8). 


\section{Convergence}

The second theme draws on the concept of 'hybridity' to describe situations where customary and modern institutions do not simply co-exist, but overlap and entwine (Boege et al., 2008). This theme traces the origins of contemporary urban governance transformation to historical processes of state formation (in particular, Tieleman and Uitermark, 2019). It notes that the British frequently included chiefs in the structure of the colonial administration as local authorities under indirect rule. Under indirect rule, individuals interact with the state through chiefs who govern autonomously in line with traditional norms prevailing in rural areas. Individuals under this system are seen as 'subjects' (of the chieftaincy). In contrast, the system of direct rule entails a model of differentiated state power in which individuals are seen as 'citizens' based on European notions of 'civilisation'. Individuals under this system are seen as 'citizens' (of the state) (Mamdani, I996). Direct rule was governed by European laws, including town and country planning acts (Njoh, 2009; Home, 20I0; Myers, 201 I). Mamdani (1996) argues that these two contrasting systems of rule, one rural and the other urban, created a 'state that was Janus-faced, bifurcated' (I8).

Case-study research challenges the rural/urban axis of the dual state by showing how chiefs have become powerful actors in urban governance through their roles as land managers, community leaders and gatekeepers, as observed in Accra (Tieleman and Uitermark, 2019). This research further shows how chiefs have embedded themselves in bureaucratic institutions in which they hold key positions, 'refining and deepening the pre-existing interdependency between the chieftaincy and the state' (Tieleman and Uitermark, 2019, 718). In many cases, state and quasi-state institutions, including utilities and NGOs, have become 'hardwired' to reach communities through chiefs. It is thus argued that far from being an archaic institution, chiefs 'often survive and occasionally even thrive during the formation of modern states' (Tieleman and Uitermark, 2019, 707).

This research departs from state-centric views of governance by exploring the political struggles through which chieftaincy and modern institutions have become interdependent. An enduring question is whether integrating the authority of chiefs within the local state has positive or negative impacts on society and governance, particularly in the context of democratisation (Mamdani, I996; Englebert, 2002; Ubink, 2008b; Baldwin, 2015).

\section{Transition}

A recent case study of three rural regions in Tanzania by Lazaro et al. (20I9) reveals how the emergence of urban centres is connected to incremental transitions in formal administrative systems. Conceptually, the study begins with an acknowledgement that 
the blurred categories of rural and urban hide emerging centres in governance. As an entry point, the authors approach settlement growth in rural regions as "in "becoming" rather than in their "being"' (Lazaro et al., 2019, 70). In doing so, they propose the concept of 'transitional spaces' (i.e. spaces in the process of becoming urban), as discussed above. Lazaro et al. trace the formal administrative stages through which an emerging settlement passes from a 'village' to a 'township' and eventually to a 'town', as prescribed in the local government act. These administrative categories are understood as coinciding with different stages of the rural-urban continuum, with the categorisation of a new 'town' representing urban status. The concept of transitional spaces allows emerging urban centres to be seen as progressing through each of these administrative stages, which can take many years.

It is equally important to understand governance prior to the advent of formal administrative systems. Most of the literature on urbanisation and urbanism in sub-Saharan Africa has focused on social change in the colonial and post-colonial periods, ignoring indigenous forms of settlement growth and settlement management in the pre-colonial period (Onokerhoraye, I975). Wekwete (I995) writes of 'town and country traditions' given the longstanding prevalence of agriculture and limited commercial activities - with the notable exception of the West African Sahel where pre-colonial urbanisms have a long history (see Baumanova et al., 20I9). While colonialism imposed a new set of rules and logics equating urbanism with formal institutions, as reflected by the conflation of 'township' with 'urban' status, pre-colonial urbanism describes a slow process of transformation in societies that share a common culture - a process that Redfield and Singer (I954) term 'primary urbanisation'. Redfield and Singer also use the term 'secondary urbanisation' to describe a process wherein a partly urbanised society is further urbanised by contact with people with very different cultures, including 'alien colonists' (Onokerhoraye, I975, 295). The distinction between primary and secondary urbanisation enables an understanding of the traditional cultures carried forward in contemporary urban change, including the ambiguous situation chiefs find themselves in where they continue to exercise their duties in accordance with tradition while simultaneously adapting to evolving urban conditions (Gutkind, I966).

\section{The governance of urbanisation in Malawi}

This section offers a background description of the historical and contemporary processes of change shaping Malawi's urban transition in the Southern African context. It then discusses the evolving role of chiefs in urban and rural governance and shows how they have become increasingly intertwined with the modern state, as demonstrated by the widespread phenomena of 'town chiefs'. 


\section{Malawi's late urban transition}

Malawi's urban transition began after the arrival of the British colonial administration in I89I and the subsequent development of colonial administrative and trading centres (UN-Habitat, 20I0a). Malawi has, however, been slow to urbanise compared to surrounding countries. Census data compiled by UNDESA (2018) indicate that as of 20I5, Malawi was the third least urbanised country in the continent following Uganda and Burundi. Malawi's low urbanisation level of I6 per cent in 2018 (NSO, 20I8), up from 8 per cent in I977 (Manda, 2013), has been attributed to its narrow and limited economy, historically dominated by agriculture and high levels of economic dependence on surrounding countries (Potts, I985).

A recent analysis of census data for the intercensal period between I998 and 2008 indicates that Malawi's annual urbanisation rate of 4 per cent is lower and slower than other agrarian African countries such as Rwanda and Uganda with similar urbanisation levels (World Bank, 20I6). At this rate, 30 per cent of Malawi's population is expected to live in urban areas by 2050. In addition to being relatively un-urbanised, Malawi's urban system is spatially imbalanced. The distribution of urban centres has been historically concentrated in the southern region as the primary site of European settlement and agricultural production (mainly tobacco and tea) in the colonial period (from i89i to I964) (Potts, I985). At independence, 75 per cent of Malawi's urban population lived in Blantyre, Zomba and Lilongwe, while the remainder of the urban system was predominated by small administrative district centres and trading posts (Kalipeni, I997). Today, the south continues to contain the majority of the urban population and urban centres, including Blantyre, the commercial capital, and Zomba, the former capital city (Manda, 20I3).

A recent assessment of census data by Manda (2013) found that 78 per cent of Malawi's urban population lived in the four largest cities in 2008, while the remaining 22 per cent lived in what are termed 'other cities' (NSO, 2008). The ambiguous criteria used by the NSO to define urban centres obscures urban size distributions, particularly at the lower end of the urban hierarchy. This is problematic given that '[o]ne of the significant elements in the increasing level of urbanisation in Malawi is the development of new, relatively small towns that are growing at fairly rapid rates' (Segal, I985, 316). While in situ urbanisation has not been studied systematically in Malawi, it is likely important given the country's small land area, high rural population densities, rapid natural increase, land pressures and dependence on agriculture (see Manda, 2013). 


\section{The role of chiefs in urban and rural development in Malawi: a brief history}

\section{Chiefs in the colonial era}

The British had little interest in the region surrounding Lake Malawi until the end of the nineteenth century when the Portuguese (who colonised neighbouring Mozambique) threatened to invade, motivating the British Foreign Office to declare the area a protectorate in I89I (Power, 20I0). Sir Harry H. Johnston, the first British commissioner to the Lake Malawi region, introduced campaigns to pacify local chiefs and signed treaties of protection that required them to accept British rule. By the time the colonial office took control of Malawi (then Nyasaland) in 1907, the colonial enterprise had moved beyond protection toward a long-term economic and political venture (Power, 2010).

Indirect rule was introduced with the District Administration (Native) Ordinance (DANO) of I9I2. The DANO replaced the previous system of tribal rule which, according to the British colonial administration, had 'fallen into decay' (quoted in Eggen, 20I I, 3i6). The DANO created a new hierarchy of 'traditional' authority led by principal headmen appointment by the district commissioner (DC) to assist in upholding general welfare. The DANO was amended in 1924 to extend the power of the principal heads to levy fines, collect taxes, hear civil cases, sell licenses and control afforestation (Cammack et al., 2009). Indirect rule was consolidated with the 1933 Native Authority Ordinance (NAO) and Native Courts Ordinance (NCO), which gave traditional authorities (now native authorities) widespread powers of local government, but under the control of the DC (Eggen, 20II). The principal headmen were empowered to make rules and orders involving 'cleanliness and sanitation, control of infectious diseases, control of fire, roadmaking, tree-felling, limitations, tax registration, reporting deaths, grass-burning, the killing of game and other administrative matters' (Chanock, I985, I08). In practice, however, chiefs' autonomy was constrained by the government's power of appointment, veto and rule-making (Cammack et al., 2009).

District councils were established as local government structures between 1953 and independence in 1964 (Chiweza, 2007). Chiefs became ex officio members of the district councils and were subordinate to them. Concern that district councils would breed anticolonialism motivated the removal of their powers under the 1954 Local Government Act, although their powers were reinstated under the I96 I local government ordinance, which for the first time required district councils to be staffed with elected officials, with chiefs continuing as ex officio members (Cross and Kutengule, 200I). The colonial government's rationale was that Malawi required a democratic local structure as it became independent. Thus, following the transfer of power to district councils at the end of British rule, the autonomy chiefs acquired during the colonial era was reduced, though the incorporation of chiefs into the local governance system provided a basis for them to retain their traditional authority (Cross and Kutengule, 200I). 


\section{Chiefs in the post-independence era}

After independence during the one-party era (from I964 to I992), the new government led by the Malawi Congress Party (MCP) under the leadership of President Kamuzu Banda emphasised 'traditional' values, giving chiefs a clear role in governance (Forester, 1994; Kalinga, 1998). The enactment of the 1967 Chiefs Act (still in force) replaced the native authority title with that of traditional authority (TA) and established their jurisdictions, but curtailed chiefs' roles to customary law and general welfare under the DC (Cammack et al., 2009).

President Banda strengthened central control through amendments to the Local Government (District Councils) Act in I966, which allowed him to appoint local councillors and dissolve the power of district councils (Cammack et al., 2009). In I967, a parallel structure of district development committees (DDCs) was established under the direct control of the office of the president and cabinet (OPC), with lower-level area development committees (ADCs) and village development committees (VDCs) chaired by chiefs (Cross and Kutengule, 200I). The power of lower-level chiefs was deeply altered under the one-party system, which demanded the loyalty of chiefs up the chain of command. While the power of chiefs over customary land did not change, they had little ability to oppose state projects and the conversion of land into ownership by political elites (Cross and Kutengule, 200I).

\section{Chiefs in the multi-party era}

Chiefs in Malawi, like many other former African colonies, experienced a resurgence following the introduction of the multi-party system in 1994, when Bakili Muluzi won the presidency (Chiweza, 2007). Eggen (201 I) attributes several changes to this development. First, the adoption of the decentralisation policy in 1996 under the Local Government Act of 1998 has not been implemented effectively in either urban or rural areas, so initiatives intended to curtail the power of chiefs in favour of locally elected councillors have widely failed (Chiweza, 2007). The situation has been exacerbated by the extended periods of time between 1994 and 2000 and between 2005 and 20I4 when there were no elected local councils in the country, allowing chiefs to become de facto leaders (Chasukwa et al., 20I4; Chinsinga, 20I5; Ministry of Lands, Housing and Urban Development, 2015). Without strong and elected local councils, DCs and DDCs continue to play crucial roles in local planning and decision-making, with chiefs often taking the lead (Cross and Kutengule, 200I). Second, weak administrative capacities at the local level have made it is extremely difficult for officials to interact with villagers except through chiefs, reinforcing their role as gatekeepers. Few government, NGO or donor projects can proceed without chiefs' approval. Third, donor policies tend to target chiefs because they are perceived to be closest to the 
community and its only representative, even though the chieftaincy is an institution that is unelected and unaccountable to its subjects. Lastly, the social legitimacy of civil servants has declined considerably following the 'culture of fear' propagated during Banda's rule, which was replaced by a culture of 'freedom' (ufulu) that included disrespect for officials. Eggen (201 I) argues that these changes have supported the 'de-traditionalisation' of chieftaincies, 'as the relative balance of "traditional" functions versus chiefs' role in modern governance has shifted toward the latter' (Eggen, 201 I, 323).

\section{The current chieftaincy structure}

There are different kinds of chiefs within each of Malawi's ethno-linguistic groups and regions. The northern part of the country is dominated by the Tumbuka and to a lesser extent the Henga, Sukwa/Ndali, Tonga and Ngonde, the latter of whom constitute the major group in Karonga Town. In the central region are the Chewa and the Maseko Ngoni, while the south is populated by the Mang'anja, Nyanja, Sena, Yao and Lomwe. The Ngonde of Karonga organise themselves in a hierarchical and centralised structure, which differs from other groups, such as the Tonga of Nkhata Bay, who are organised around loosely based clan governance (Power, 2010).

Malawi's chieftaincy structure is defined by the Chiefs Act of ig67, which establishes chieftaincies as hierarchical and hereditary. At the top of the hierarchy are paramount chiefs (PGs) or TAs (where there are no PGs) who are represented within all ethno-linguistic groups. Below the PC/TA level are sub-TAs (STAs), group village headmen $(\mathrm{GVH})$, and village headmen $(\mathrm{VH})$, all referred to as 'chiefs' by Malawians. All villages have a $\mathrm{VH}$ under one $\mathrm{GVH}$, and all chiefs have a group of councillors who are usually relatives or close acquaintances. While chiefs are hereditary, the Chiefs Act gives the OPC the power to approve or decline new chiefs and to create new chiefs and TAs (Cammack et al., 2009).

Although chiefs have established authority in rural areas, their status in urban areas is much less clear (Cammack et al., 2009; Chinsinga, 2015). Both the Chiefs Act and the Local Government Act do not recognise the authority of chiefs in urban areas. Conversely, the Town and Country Planning Act of r99 I recognises the authority of chiefs to allocate customary land in statutory planning areas so long as titles are acquired and basic layout plans followed, although the declaration of a planning area does not inherently change the legal status of land or the authority over it (Ministry of Lands, Housing and Urban Development, 2015). This ambiguity makes it difficult to discern the de jure and de facto authority of chiefs in urban areas, often placing them at odds with local councils (Cammack et al., 20o9). Town chiefs nevertheless control large amounts of urban land, as in Zomba and Mzuzu, where customary land dominates available urban land at 9I per cent and 75 per cent, respectively (UN-Habitat, 20I0a). 
Customary land constitutes one of three land tenure systems in the country, which also include public and private land. Public land is defined as that which is occupied, used or acquired by the government, while private land is defined as that which is held under freehold or leasehold title. In contrast, customary land is held or used under customary law, which varies throughout the country depending on the rules and norms of the dominant ethnic group (Liuma, I998; Msisha, I998; Kishindo, 2004). There are common aspects of customary law, namely that land is viewed as a gift from God to communities for their subsistence, land belongs in lineages (kinship is the main factor determining access to land), and land is held in trusteeship for communities by chiefs, who can allocate land, but cannot own it (Msisha, I998).

With urbanisation, customary land markets have begun to commercialise as land pressures have mounted (UN-Habitat, 20Ioa). Chome and McCall (2005) draw on Durand-Lasserve's (2003) concept of 'neo-traditional customary practices' to describe this process in Malawi, where re-interpreted customary practices combined with new informal and formal practices of land delivery, have proven far more effective than formal systems especially among the urban poor. Estimates indicate that up to 70 per cent of Malawi's urban population lives in informal settlements (Manda, 2013). While data on the three main land tenure systems are unavailable for all urban centres in the country, customary land is likely to be more prevalent at the bottom of the urban hierarchy, where existing land is held principally under customary law.

\section{'Town chiefs' in practice}

'Town chiefs' have been a major focus within Malawian urban studies (for example, Chirwa, 2005; Chome and McCall, 2005; Cammack et al., 2009; Eggen, 20 i ; O’Neil et al., 2014; Chinsinga, 2015; Refstie and Brun, 2016; Refstie and Millstein, 2019). The most comprehensive study by Cammack et al. (2009) examined the role of town chiefs in fourteen urban centres, including Lilongwe, Dowa, Ntchisi, Kasungu, Balaka, Blantyre, Zomba, Mponela, Mzuzu, Rumphi and Bolero, Mzimba, Nkhata Bay and Karonga Town. The study reveals the different functions of town chiefs, ranging from land management to local development, conflict resolution, involvement in elections, social and cultural affairs (notably funerals) and community mobilisation. Cammack et al. draw three important conclusions. First, town chiefs are a form of hybrid governance that emerged from the historical process of state formation. Chiefs serve purposes that are both historical and modern. Second, town chiefs should not be equated with 'traditional' social norms since they have adapted to urban conditions, including the absence of state recognition. Last, towns chiefs help communities to overcome collective problems by bringing together opposing groups and introducing rules that allow communities to gain access to public goods. The cost, however, is a 
governance system that is antithetical to the liberal democratic ideals of the formal state, as discussed earlier.

While town chiefs are culturally recognised throughout the country, their authority is not legally recognised in towns, cities and municipalities under the Chiefs Act (Chinsinga, 2015). Under indirect rule, it was government policy in the colonial era to leave Malawians to their own ways of living outside of the cities, where the British lived. To avoid conflicts between modern/urban and customary/rural land administration systems, chiefs were not given authority in urban areas - a policy that remains unchanged under the Chiefs Act (Chirwa, 2005). This policy effectively sets the stage for the two systems to overlap in urbanising rural territories. For instance, a case study by Chirwa (2005) shows how the physical expansion of Mzuzu City has led to dual land administration systems following the incorporation of land within the jurisdiction of chiefs and how chiefs have undermined the implementation of the urban structure plan by allocating customary land, resulting in the spread of informal settlements and conflicts with the city council. This situation is not uncommon in other Malawian towns and cities (see Chinsinga, 2015).

Another study of rural villages surrounding Zomba City by Eggen (201 I) shows how the boundaries between customary and state institutions have become increasingly permeable due to the diffusion of direct forms of rule into rural areas without eliminating chiefs' authority. In such cases, individuals have become 'simultaneously citizens and subjects'. Importantly, the observations made by Chirwa (2005) and Eggen (20II) demonstrate how rural governance is affected when the state attempts to spread its authority into peripheral areas, leading to overlaps and conflicts with customary systems.

\section{The governance of urban development in Karonga Town}

This section reviews what is known about local governance in Karonga Town based on existing literature and primary data collected during the fieldwork. It will show the rural governance transformations triggered by in situ urbanisation, and the consequences for the planning system.

\section{Karonga Town's emergence}

Karonga is an emerging urban centre in the northern-most and least urbanised part of Malawi. The town is situated at the mouth of the North Rukuru River and on the shores of Lake Malawi in Karonga District, which is predominately rural. The area around the town's present location was settled by the Ngonde tribe who arrived around the turn of the seventeenth century (Kalinga, I980). The Ngonde were attracted to the Karonga lakeshore plain for its fertile alluvial soils, high rainfall and proximity 
to fresh water sources. Favourable environmental conditions enabled the Ngonde to develop agriculture (notably maize, millet, cassava, beans and rice) and fishing as the backbone of the economy, to emerge as a relatively stable and self-sufficient society, and to establish a centralised political system (Kalinga, I979).

Little is known about Karonga Town's historical growth and development in the absence of detailed data and research. Available information indicates that the town's origins extend back to the late I880s when Mlozi, a Swahili slave trader, established a trading post in the Kambwe area located about $8 \mathrm{~km}$ north of the town's present location (Kalinga, I980). The British colonial administration, which arrived in I89I, established a British overseas military area (BOMA) - in which district councils were initially located - at Kambwe in I895 before moving it to the present settlement in I904 (Manda et al., 20i6). Following the First World War, the town's growth was spurred by several infrastructural developments, including the construction of the town's first hospital in I93I, an airfield in I947 and St Mary's Secondary School in I955 (Ministry of Lands and Housing, 2013) . In I959, frequent out-bank river flooding in the Kambwe area combined with its narrow harbour led to the relocation of the BOMA to the area along the lakeshore known today as 'old town' (Manda et al., 20I6). Much of this area was destroyed by a major flood in I979. The district council offices were subsequently shifted to the south-east by approximately $2 \mathrm{~km}$ to avoid flooding (Manda et al., 20i6).

The northern region was viewed as the 'dead north' until I988, when the Mi Road, referred to later as the 'northern corridor', was extended to the Tanzanian border at Songwe (McCracken, 2003). The extension of the Mi positioned Karonga Town as the first major urban centre and stopover point between Malawi and Dar es Salaam. Since ig66 (the first census year), the town's population has grown more than five-fold from II,242 to 61,6og in 2018 (the last census year) (NSO, 2018). Karonga Town is now the fifth largest urban centre in the country, although it is considerably smaller than the three largest cities (Lilongwe, Blantyre and Mzuzu), which together with Zomba comprise most of the urban population (NSO, 2018) (Figure I). Karonga Town's growth is attributed largely to a very high fertility rate of 5.7 , reflected by the predominance of young people in the age structure (Ministry of Lands and Housing, 20I3). These trends are consistent with situ urbanisation dynamics. Given the town's function as a trading centre in the north, in-migration will likely play an increasingly important role in the town's future growth.

\section{Rural governance transformation}

\section{Planning finds the town}

Karonga Town was declared a statutory planning area in I99I under the Town and Country Planning Act of I988. By then, its population was already around I9,0oo 


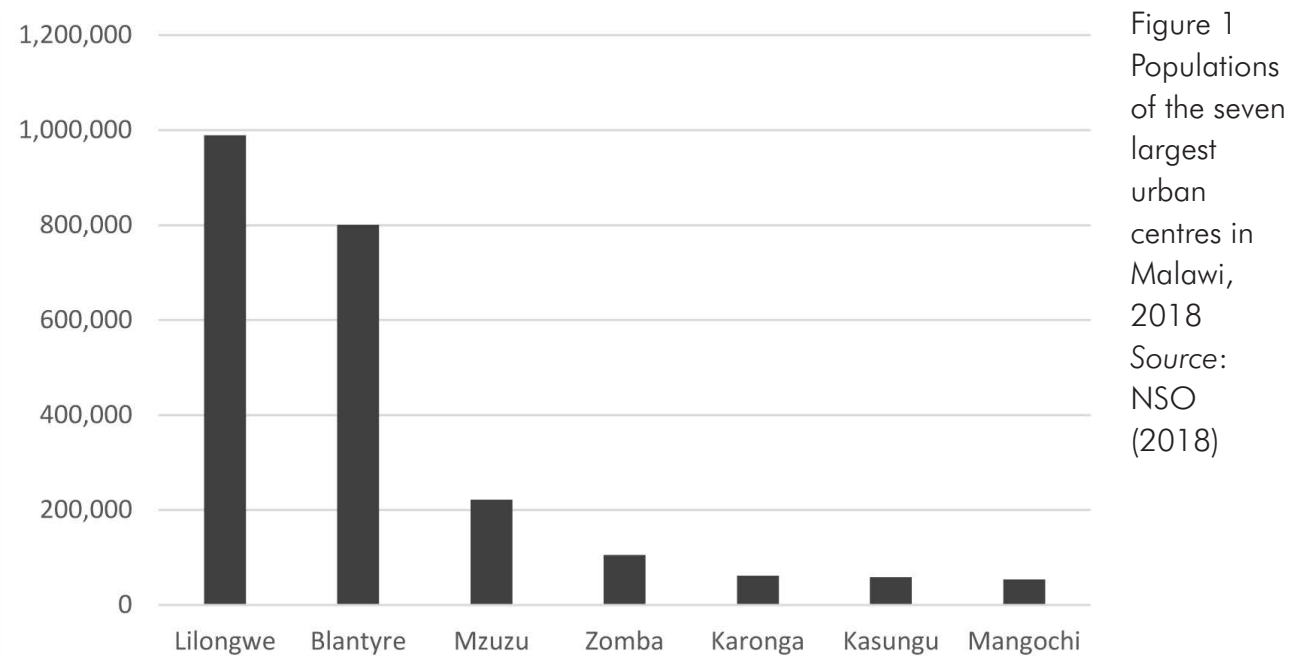

(Figure 2). Thus, by the time planning 'found the town', as one planner remarked, Karonga Town was already an emerging urban centre with an established governance structure controlled by hereditary chiefs. As Cammack et al., (2009) observe,

There appears to be a difference between traditional authorities who have been 'found' by towns/continue to exercise jurisdiction within towns - a type that may be more prevalent in the less urbanised North - and local leaders in towns who have been 'created' by officialdom and/or residents to fill a gap and are modelled on traditional chieftaincy. (35)

Attempts to impose a formal planning system in Karonga Town have been met with staunch resistance among chiefs. Government efforts to relocate communities from 'disaster-prone areas' exemplify the situation. Following the flood disaster in I979, as discussed above, large swathes of the lakeshore area, including much of 'old town', were designated as flood-prone areas. The policy of the current urban structure plan is to relocate the population so that flood-prone areas can be developed into 'public open spaces for recreation' (Ministry of Lands and Housing, 2013, 36). The plan assumes that communities would be willing to voluntarily relocate to safer areas. Meanwhile, the district council has continued to allocate land in these areas anyhow. As an official from the physical planning department explained,

Unfortunately there has been a lot of resistance in Karonga. Actually you find that because these disasters or floods come after so many years, people forget. They will think maybe it is a once in a while thing, and they see land that is remaining idle, there are some interests, and you find that our sister departments, maybe the [District] 


\begin{tabular}{ll}
\hline Year & Population \\
\hline 1966 & 11,242 \\
\hline 1977 & 12,051 \\
\hline 1987 & 19,630 \\
\hline 1998 & 27,816 \\
\hline 2008 & 41,074 \\
\hline 2018 & 61,609
\end{tabular}

Figure 2

Population

of Karonga

Town,

1966-2018

Census data for 1966-2007 presented in Ministry of Lands and Housing (2013)

Census data for 2018 presented in NSO (2018)

Council and the [Ministry] of Lands, will proceed to allocate lands that we have designated as a risk area.

Communities refuse to relocate based on concerns over compensation, the perception that the most important risks people face are loss of livelihoods, and most importantly the tradition of burying deceased family members close to where they live (Figure 3). As one chief explained,

The government insisted that people should move from this area. Go to other areas, way upwards there. But we say that this is our forefathers land. We cannot move from this to other places. If we must die, let us die here. That is why we put graves here next to our houses. When they say we should go upland, I said no I cannot leave my forefather's graves here. Yes, we are sitting on graves.

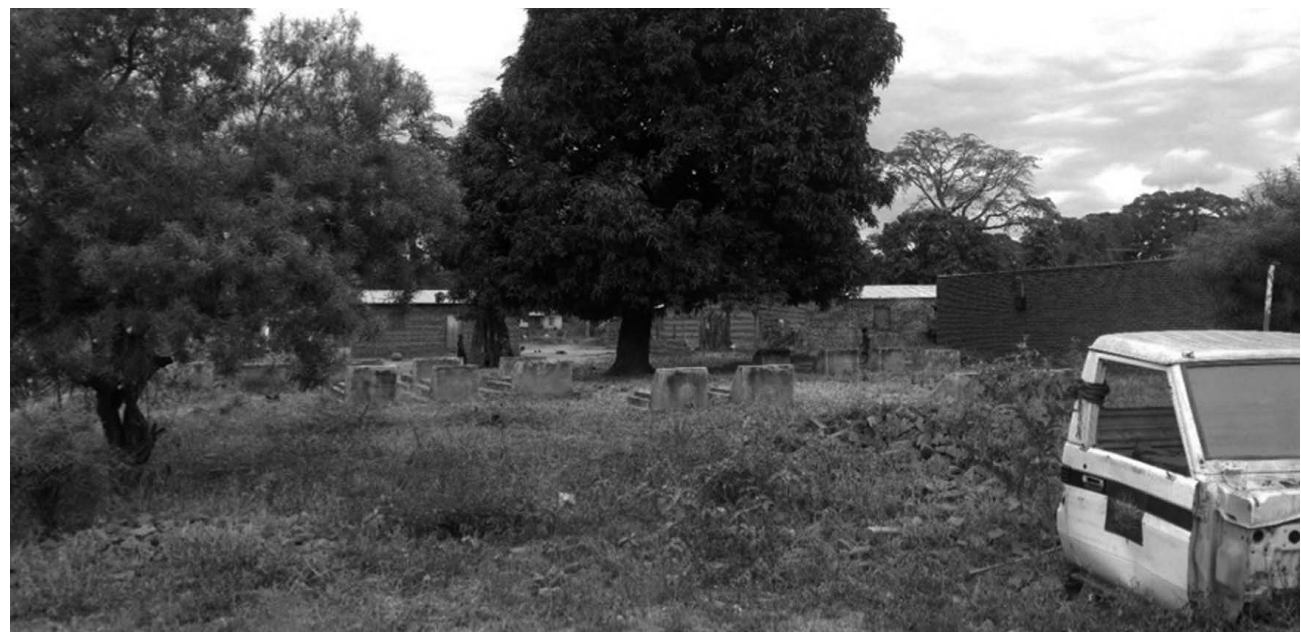

Figure 3 Graveyard in residential area, Karonga Town Source: Author (2017) 
Given the refusal of communities to relocate, planners are calling for new legislation that would give them powers to declare disaster-prone areas as 'no go zones'. As the head of the physical planning department explained,

The plans that we prepare are not supposed to be just advisory. They are supposed to be legal instruments, but sometimes people insist that, ah! No, no. I will put masonry here, I protect and put a retaining wall here, and floods can't come here. But later still things happen.

In the present circumstance, it is difficult to imagine how the urban structure plan could have an impact on urban development (including relocation) if it would require the community to abandon their cultural norms and traditions, many of which are rooted in the places in which they have always lived.

\section{Planning without a town council}

Decentralisation in Malawi was reintroduced following multi-party elections in I994, when the Local Government Act of 1998 in conjunction with the Decentralisation Policy of 1996 were adopted in the hope of promoting grassroots institutions and community participation in decentralised planning frameworks (Chinsinga, 2007), as discussed above. The first local elections were held in 2000, but were discontinued in 2005 for the reasons below. Amendments were subsequently made to the Local Government Act to dissolve all town councils. No local elections have been held in Karonga Town since the local councillors' first term ended in 2005, even though local elections were reinstated in other parts of the country following tripartite national elections in 2013 (Manda, 20I4). In effect, the town's governance structure has been ruralised (or de-municipalised). Officials widely acknowledge the need to reinstate the town council given the town's size and continued growth, but the minister of local government has not done so. Planners familiar with the situation attribute this failure to 'politics' writ large based on the view held among national politicians that decentralised structures are unnecessary and that local councillors represent a threat to national authority (see also Manda, 20I4). Figure 4 compares the town's current governance structure (right) to the typical governance structure intended for urban centres in Malawi (left).

Planners identified major differences between these structures:

- City councils function as their own districts, with their own elected representatives (including mayors and ward councillors) and powers to prepare, enact and enforce local physical development plans. Conversely, Karonga Town was merged with the Karonga District Council when local elections were suspended in 2005. The town therefore has no administrative structure at the urban scale; 
Typical urban governance structure

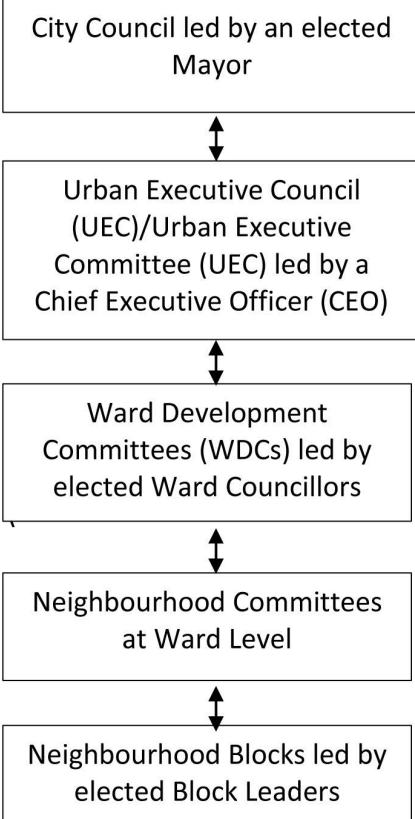

\section{Karonga Town's governance structure}

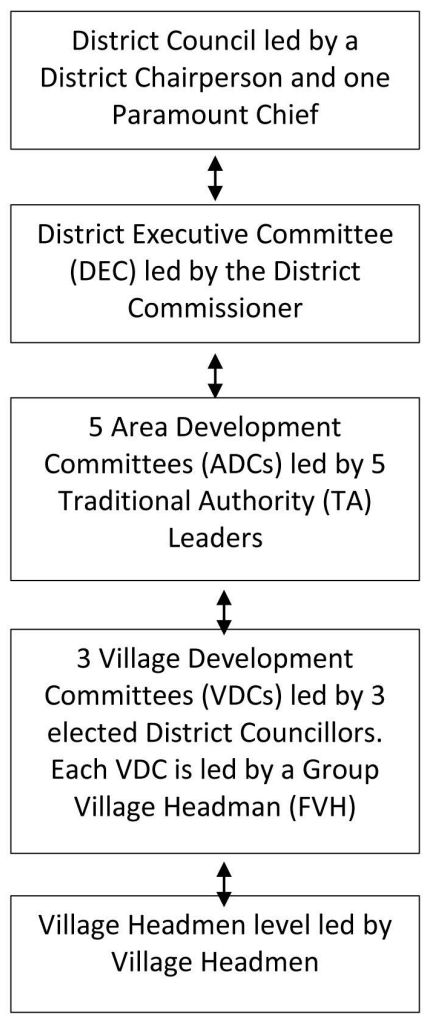

Figure 4 The governance structure for Karonga Town compared to the typical governance structure for urban centres in Malawi Source: Author (2017)

- City councils are headed by elected mayors who oversee a defined urban jurisdiction (a city/municipality). Conversely, the Karonga District Council is headed by a politically appointed district chairman who oversees the entire district;

- City councils govern consolidated spatial areas disaggregated into wards, neighbourhoods and blocks. Conversely, the Karonga District Council governs the entire district, encompassing five ADGs at the TA area level under one paramount chief. The purpose of ADGs is to communicate local needs to the district executive committee (DEG), which decides which local development projects to support. Beneath the ADCs are numerous VDCs, each controlled by a GVH. VDCs identify local problems and prioritise local development projects, which are then communicated to the ADGs. Karonga Town has one ADC, which includes rural VDGs beyond its administrative boundary; 
- City councils are comprised of Ward Development Committees (WDCs) consisting of neighbourhoods and blocks. Each WDG has an elected ward councillor, each neighbourhood has an elected leader, and each block has an appointed leader. Conversely, Karonga Town is comprised of three VDGs: Mwahimba, Mweninyumba and Katolola. VDCs are not supposed to exist in urban areas, since they are rural structures. Each VDC (roughly equivalent to the neighbourhood level) is controlled by a GVH who oversees $\mathrm{VH}$ at the sub-village level (VDCs are comprised of numerous villages). There are no elected leaders beneath the VDC level and there are only three district councillors for the town;

- City councils recognise the mayor, ward councillors and block leaders, but do not recognise chiefs (locally termed 'blood leaders') who are relegated as ex officio members of local councils. Conversely, there is no formal government structure below the VDC level in Karonga Town, allowing chiefs to govern semi-autonomously;

- City councils have their own municipal budgets that ward councillors compete for. Conversely, VDGs in Karonga Town must compete with other VDCs for scarce resources at the district level.

Planners identified various institutional constraints associated with having a rural governance set up for an urban area:

- It is inherently less representative, participatory and accountable to urban dwellers. This is in part because a) city councils have a more devolved leadership structure at the ward and city levels, whereas district councils have a centralised structure at the VDC and ADC levels (encompassing urban and rural areas), and (b) chiefs retain a large amount of power and influence over decision-making at the local level, even though they are not elected nor necessarily accountable, transparent or fair;

- It creates potential for conflict and power struggles between chiefs and district councillors. The former often have more social legitimacy than the latter;

- It makes it possible for chiefs to undermine the decisions and plans of the district council, particularly given their role in land allocation. Few formal checks and balances are in place at the local level, particularly in the absence of a regular town planning committee;

- It positions customary institutions as the primary governing entities at the community level. Chiefs uphold customary rules, norms and traditions and serve as the custodians of land, pitting them against formal land management structures, particularly those seeking to take away their power;

- It means that there is no local mechanism to enforce development control, leaving chiefs to manage land as they see fit, despite official rules and regulations;

- It means that the district council lacks the bureaucratic and fiscal capacity to meet the development needs of the town and respond to the demands of citizens; 
- It means there is insufficient local political representation to support grassroots participation in planning and decision-making.

The vacuum created by the dissolution of the town council allowed chiefs to reclaim much of their control over land and thus society and governance. The decision has had major impacts on Karonga Town's planning system, particularly the loss of command-and-control power and shifts in the balance of power.

\section{Loss of command-and-control power}

Following the removal of the town council, planning was transferred upwards to the district council, which employs one physical planner for the entire district, encompassing a vast rural territory and several other towns, including Chitipa and Songwe. These towns should have urban structure plans, but do not due to capacity deficits. Meanwhile, without sufficient resources, the town planning committee (responsible for reviewing planning and building applications) meets annually rather than quarterly as it once did, while the plot allocation committee (responsible for allocating plots to interested people in newly planned areas) 'is almost dead', according to a senior district official.

District officials have become increasingly frustrated over their inability to control urban development. One official blamed local culture for the situation:

People are not following standards. This is a challenge. You can find that if you go into the township, the government is intending to demarcate plots so that people can build better houses. And you will find natives. You go with a grader trying to grade lots for a township to look neat, but you will find that people have encroached those places. Wherever you build a road somebody's building a house there. So it becomes a challenge to cooperate. So culture now comes in. So it is a something that is trying to defeat the whole purpose of what you want a township to look like. It is culture versus the development we are trying to bring.

While many officials view stricter development control enforcement as the solution to 'informality', one senior district official explained that this would result in 'war' with communities:

The relationship [between the district and communities] is a plastic one. It's a fake one because as a council we are not doing a lot of enforcement... Should we start biting, then the relationship will become sour because what we want to do is something that cannot make them happy. But by the end of the day the town will be organised and coordinated when we start biting. When we start for example to take our grader, tractor start demolishing structures and plant in new structures there will be a war.

At the same time, chiefs have become increasingly reluctant to accept the imposition of the formal planning system. As one GVH remarked: 
We are out of the town, but we are within the town... but the people living here feel they are not. We were here before the town's plans were drawn. The people came and then they said we are going to make Karonga a town.

This quote reflects the challenges of formalising a town well after it has emerged, pitting modern institutions against chieftaincy institutions in a struggle over territorial control.

\section{Shifts in the balance of power}

As major landholders and gatekeepers to communities in Karonga Town, chiefs hold significant power. Development projects by NGOs and the district council cannot proceed without first receiving the approval of chiefs, who are heavily involved in decision-making. The town's three VDGs (Mwahimba, Mweninyumba and Katolola) are part of the district development planning system established to increase participation in decision-making at the grassroots level. VDCs serve as local platforms for communities to identify problems (e.g. education, disease, sanitation, food security, floods, strong winds, fires) and local development priorities and to communicate them to the ADC, as discussed above. VDC meetings are held once a month and led by ten to twelve elected community members plus an elected chairperson, many of whom are chiefs. As one chief explained,

I attend those meetings and get to speak there... We support the principal GVH [group village headman]. If there are problems, we tell him and call a meeting with people, to speak to people, and people speak their views. Some bylaws are made at the meetings to overcome the problem ... Along the river, there were bylaws. There should be nobody cultivating 20 metres from the river. This is followed by everyone. No one misconducts the bylaws for the village headmen. If they do, they are required to compensate [pay a fine].

Chiefs indicate that the district council does not frequently participate in VDC meetings and that it generally takes a long time for the district council to respond to problems:

It takes time. Sometimes we can call councillors and MPs [Members of Parliament] and sometimes they don't come. If they can come, they can say yes, we get your problem, you wait. So we keep waiting and waiting. Some do respond, but others do not.

Through their involvement in local decision-making, chiefs have been able to negotiate for public facilities. One chief worked closely with district councillors and MPs to obtain funding from the national government's local development fund (LDF) to construct a primary school. The site proposed by the chief was allocated and surveyed by the Ministry of Lands, even though the site is located in a floodprone area, as demarcated in the urban structure plan. As the GVH explained: 
In our operations, we work closely with the councillors who identify projects. In fact, in the villages, we have priorities. A councillor will visit here and say what are our priorities. For example, now we asked the Member of Parliament to construct a school and it is being done now, it has just started. So the link between the chiefs and the DC [District Commissioner] is also through the councillors... So when you ask me about the DC, we work hand-in-hand.

In the present circumstance, chiefs provide the main link between the district council and communities. Meanwhile, the district council has lost much of its social legitimacy given its inability to fulfil its basic mandate, including urban planning and service delivery (see Manda, 20I4). Pre-existing forms of organisation based on customary institutions have subsequently grown in importance as a way of gaining access to public goods. Given this situation, chiefs can be seen as representing a form of hybrid governance: they perform functions with historical and modern purposes, they fill a local governance vacuum, and they address problems arising from urban development, including the need for basic services and public facilities. Cammack et al., (2009) made similar observations in other Malawian towns and cities, indicating a wider socio-political culture in the country.

\section{Discussion and conclusion}

This article has sought to understand how rural regions urbanise, and how rural governance transforms in the process. The article has presented a detailed case study of Karonga Town situated in a broader historical and contemporary account of Malawi's urban transition and evolving governance structure with the larger aim of operationalising a comparative research agenda on the governance of in situ urbanisation. Several observations stand out from Karonga Town that may be of broader relevance to other emerging urban centres in Malawi and beyond.

First, how rural settlements become urban involves a combination of endogenous and exogenous factors. At the initial stages of in situ urban change, natural increase is the main driver of population growth (Africapolis, 2009). Later in the process, in-migration may become important where non-agricultural activities present opportunities for livelihood diversification, as observed in Ghana's coco frontier (Knudsen and Agergaard, 2015). While fertility rates in Karonga Town remain high at around 5.7 (Ministry of Lands and Housing, 20I3), the town is attracting growing numbers of migrants seeking livelihoods in small-scale trade (including vending, carpentry, basket making, blacksmithing, electronic repairs, hair dressing, etc.), hospitality, transport, fishing and agriculture. These growth drivers are similar to those of other emerging urban centres propelled by demographic expansion alongside economic diversification, as observed in Tanzania (Bryceson, 201 I). 
Interestingly, Karonga Town's growth trajectory does not support the hypothesis that rural areas may transform into small towns more slowly where local state capacity is limited and public services are not provided, thus discouraging migrants and investment. The absence of a town council since 2005 coincided with a period of rapid unplanned growth, leading to the accumulation of environmental risks, notably seasonal floods and recurrent cholera outbreaks (see Manda and Wanda, 2017; Brown, 2020). It is possible that the town's growth could slow if these risks increase mortality rates and/or decrease in-migration, yet the town's population is continuing to grow at 5 per cent per annum (NSO, 2008; 2018). Nevertheless, considering that Karonga Town is now an established marketplace and service centre, it has clearly emerged as a small town, underscoring the need to understand the context-dependant nature of urban change.

Second, the notion that rural governance transformation involves the administrative 'transition' from a 'village' to a 'township' and eventually to a 'town', as envisaged by Lazaro et al. (2019) does not fully describe the complicated experience of Karonga Town. Without a town council, township status is merely on paper. Meanwhile, the bureaucratic and fiscal capacity to meet local development needs at the district level is severely lacking, so citizens continue to rely on chiefs to access public goods. It is therefore difficult to assess how much rural governance transformation is attributed to administrative 'transition' or rather to the resilience of customary institutions, which serve both modern and traditional purposes. This observation reaffirms the need to understand how traditional cultures are carried forward in contemporary urban change (Gutkind, I966; Onokerhoraye, I975; Redfield and Singer, I954). However, while there is some evidence indicating the positive role of town chiefs in community mobilisation through their roles as community leaders, gatekeepers and the heads of local development committees (Refstie and Brun, 20I6; Refstie and Millstein, 2019), there are longstanding concerns that communities remain highly dependent on chiefs (and other patrons) in the absence of democratic state actors (Cammack, 2007).

Third, most chiefs in rural areas are hereditary. So 'when planning found the town', it also found hereditary chiefs. This situation differs from more established urban areas in Malawi where different kinds of chiefs have emerged, including those who have assumed their positions through election or appointment, as documented by Cammack et al. (2009). Many hereditary chiefs in Karonga Town voice a strong unwillingness to abandon traditional systems in favour of formal administrative systems, as reflected by the continued existence of VDCs, which are intended for rural areas. Looking forward, the ability of the formal planning system to effectively manage the town's growth will depend largely on whether the local state is able to re-establish its presence and social legitimacy. Whether the current planning system, with its origins in the master planning tradition, is appropriately suited to local conditions is another matter. 
Fourth, in situ urbanisation creates different institutional complexities than in larger metropolitan areas characterised by fragmented institutional and administrative systems and complicated bureaucracies (Auerbach et al., 2018): institutional environments in emerging urban centres may be uniquely complex where chiefs control large amounts of customary land, it takes time to establish the legitimacy of newly elected bodies, civil society lacks presence, and local governments are weak or non-existent. Conversely, institutional environments in emerging urban centres may be uniquely un-complex where local elites know each other and are easier to engage, different government departments are more willing to collaborate, smaller and more intimate bureaucracies make inter-sectoral coordination easier, and local governments are willing to partner with communities. How local institutions can be designed to address the growth dynamics and governance conditions particular to emerging urban centres is a key question for further research.

Last, as transitional spaces, emerging urban centres display governance challenges similar to those observed in peri-urban areas as another form of transitional space. For instance, peri-urban areas may also have overlapping administrative and institutional systems where urban authorities attempt to extend their authority into outlying areas controlled by chiefs, as observed in peri-urban Mzuzu (Chirwa, 2005), or where chiefs fill the void created by weaknesses in the local state through their leadership roles, as observed in peri-urban Blantyre (Cammack, 20I2). In such instances, the capacity to prepare and enforce plans, facilitate grassroots participation in decision-making and establish formal administrative systems may face similar social and institutional constraints as in emerging urban centres, especially those with weak and illegitimate local governments. How governance conditions in emerging urban centres compare with those of other transitional spaces represents another area for comparative research.

The observations above indicate that in situ urbanisation is a distinct form of urban transformation with distinct social and institutional implications that challenge existing theories about urban governance (see Auerbach et al., 2018), hence the need for a larger comparative research agenda on the subject. As an established field of urban studies, comparative research seeks empirical observations and theoretical insights into processes of urban change within and between regions (McFarlane and Robinson, 2012; Robinson, 20I5), with a particular interest in smaller, more 'ordinary cities' (Robinson, 2002; 2006; Bell and Jayne, 2009). While this interest has increased in recent years, particularly in view of urbanisation trends, it traces back to the late I970s when scholars drew attention to the role of 'small towns' in rural-urban development, with specific reference to sub-Saharan Africa (for example, Rondinelli and Ruddle, I978; Hardoy and Satterthwaite, I986; Baker, i990; Baker and Pedersen, I992; Simon, I992; Pedersen, I997). This article seeks to build on this literature by positioning 'transitional spaces', as conceived by Lazaro et al. (2019), as a distinct 
terrain of comparative research on smaller centres, based on the detailed case study.

Case studies are widely recognised as a valuable means of comparative urban research where the objective is to understand the specificity of context, while also allowing observations and conclusions to be compared and drawn across contexts (Robinson, 20II; Duminy et al., 2014; Watson, 2012). In order to position Karonga Town at the forefront of the agenda proposed here, it is first necessary to consider the conditions that make it generalisable to other cases. These conditions capture the general characteristics of emerging urban centres and fall into several categories:

- demographic: population sizes at or near the bottom of the urban hierarchy, rapid natural increase and changing patterns of in-migration (seasonal, permanent);

- spatial: the densification and consolidation of the settlement;

- temporal: emergent urban characteristics linked to changing occupational structures and settlement patterns;

- geographic: location in rural regions dominated by agriculture;

- economic: small economic hubs (large villages) and larger marketplaces and service centres (small towns);

- socio-cultural: the predominance of one ethno-linguistic group who settled the area;

- institutional: the existence of hereditary chiefs and local governments (often weak or non-existent);

- administrative: settlements classified as 'villages', 'townships', 'towns' or their equivalents.

These conditions direct our attention to places that are, to various extents, becoming urban, some in more ways than others. For instance, Karonga Town is a township with a population over 6o,ooo, yet it has no town council. Conversely, a small town may not be declared a township or have a town council, despite having a rapidly growing population and economy. Because there will be variations between emerging urban centres depending on, for example, their size, level of development and degree of formalisation, their conditions are not proportionate. Importantly, variations can lead to more nuanced observations and theories in different circumstances and stages of change. So while the selection criteria (based on the conditions above) should be applied carefully, they should not be applied narrowly to 'control for variation', which could stifle comparative exploration (Robinson, 20I I). Here, the intention is not simply to generalise the findings from one case to another, but rather to understand the uniqueness and differences in how rural governance transforms in the process of in situ urbanisation.

Ultimately, supporting a comparative research agenda on small town governance and in situ urbanisation has the potential to make a significant contribution to the literature seeking to reveal the informality in different governance landscapes and 
the forms of urbanisation in which these landscapes are embedded in sub-Saharan Africa and beyond. It is the hope that this article will help to provide the empirical, conceptual and methodological way forward toward the generation of new observations and insights into the growth dynamics and governance conditions particular to emerging urban centres.

\section{Acknowledgements}

I would like to thank my doctoral supervisors, Cassidy Johnson and David Osrin, for their unwavering support and guidance throughout the research process. Profound gratitude also goes to Mtafu A. Z. Manda for his friendship and interest in my work. This research would not have been possible without Khumbo Kumwenda who assisted me in the field. Last but not least, I would like to thank the two reviewers for their valuable comments and insights.

\section{References}

Africapolis (2009) Urbanization Trends 1950-2020: A Geo-statistical Approach. West Africa, Paris, Agence Française de Développement.

Agergaard, J.. Tacoli, C., Steel, G. and Borby Ørtenblad, S. (20r9) 'Revisiting rural-urban transformations and small town development in sub-Saharan Africa', The European fournal of Development Research, 3I(I), 2-II.

Allen, A., da Silva, N. L. A. and Corubolo, E. (I999) 'Environmental problems and opportunities of the peri-urban interface and their impact upon the poor' (Discussion Paper), London, Development Planning Unit, University College London.

Auerbach, A. M., LeBas, A., Post, A. E. and Weitz-Shapiro, R. (2018) 'State, society, and informality in cities of the global South', Studies in Comparative International Development, 53(3), 26I-280.

Baker, J. (1990) Small Town Africa: Studies in Rural-urban Interactions, Uppsala, Scandinavian Institute of African Studies.

Baker, J. and Pedersen, P. O. (eds) (1992) The Rural-urban Interface in Africa: Expansion and Adaptation, Uppsalla, Scandinavian Institute of African Studies.

Baldwin, K. (2015) The Paradox of Traditional Chiefs in Democratic Africa, New York, Cambridge University Press.

Baumanova, M., Smejda, L. and Rüther, H. (2019) 'Pre-colonial origins of urban spaces in the West African Sahel: street networks, trade, and spatial plurality', Journal of Urban History, $45(3), 5^{00}-5^{\mathrm{I} 6}$.

Beauchemin, C. and Bocquier, P. (2004) 'Migration and urbanisation in francophone West Africa: an overview of the recent empirical evidence', Urban Studies, 4I(I I), 2245-2272.

Beegle, K., De Weerdt, J. and Dercon, S. (2010) 'Migration and economic mobility in Tanzania: evidence from a tracking survey', The Review of Economics and Statistics, 93(3), Ioro-I033. 
Bell, D. and Jayne, M. (2009) 'Small cities? Towards a research agenda', International fournal of Urban and Regional Research, 33(3), 683-699.

Boamah, F. (2014) 'How and why chiefs formalise land use in recent times: the politics of land dispossession through biofuels investments in Ghana', Review of African Political Economy, $4 \mathrm{I}(\mathrm{I} 4 \mathrm{I}), 406-423$.

Boege, V., Brown, A. and Clements, K. (2008) 'On hybrid political orders and emerging states: state formation in the context of "fragility", Management, (8), http://edoc.vifapol.de/ opus/volltexte/20i I/2595/(accessed io March 2020).

Brown, D. (2020) 'The strengths and limitations of using hospital records to assess environmental health in Karonga Town, Malawi', Environment \& Urbanization, 32(I), 233-256.

Bryceson, D. F. (I999) 'African rural labour, income diversification \& livelihood approaches: a long-term development perspective', Review of African Political Economy, 26(80), I7I-I89.

Bryceson, D. F. (201 I) 'Birth of a market town in Tanzania: towards narrative studies of urban Africa', Journal of Eastern African Studies, 5(2), 274-293.

Bryceson, D. F., Jønsson, J. B., Kinabo, C. and Shand, M. (2012) 'Unearthing treasure and trouble: mining as an impetus to urbanisation in Tanzania', Journal of Contemporary African Studies, 30(4), 63 I-649.

Cammack, D. (2007) 'The logic of African neopatrimonialism: what role for donors?', Development Policy Review, 25(5), 599-6I4.

Cammack, D. (2012) 'Peri-urban governance and the delivery of public goods in Malawi, 2009-II' (APP Research Report No. 3), Malawi, IEDD.

Cammack, D., Kanyongolo, E. and O’Neil, T. (2009) "Town chiefs" in Malawi' (Working and Discussion Papers), https://www.odi.org/publications/II499-town-chiefs-malawi (accessed io December 2019).

Chanock, M. L. (1985) Law, Custom and Social Order, Cambridge, Cambridge University Press.

Chasukwa, M., Chiweza, A. L. and Chikapa-Jamali, M. (2014) 'Public participation in local councils in Malawi in the absence of local elected representatives: political eliticism or pluralism?', Journal of Asian and African Studies, 49(6), 705-720.

Chinsinga, B. (2007) 'District assemblies in a fix: the perils of self-seeking tendencies in decentralisation policy reforms in Malawi', Africa Development, 32(I), 89-II I.

Chinsinga, B. (2015) The Political Economy Analysis of Urban Governance and Management in Malawi, Lilongwe, Tilitonse.

Chirwa, S. (2005) 'Amendment of the role of chiefs in urban land management', in Lessons in Urban Management: Experiences in Malawi 2000-2005, Mzuzu, ALMA Consult, 46-54.

Chiweza, A. L. (2007) 'The ambivalent role of chiefs: rural decentralization initiatives in Malawi', in L. Buur and H. M. Kyed (eds), State Recognition and Democratization in Sub-saharan Africa: A New Dawn for Traditional Authorities? New York, Palgrave Macmillan, 53-78.

Chome, J. and McCall, M. (2005) 'Neo-customary title registration in informal settlements: the case of Blantyre, Malawi', International Development Planning Review, 27(4), 45 I-477.

Christiaensen, L. and Todo, Y. (2014) 'Poverty reduction during the rural-urban transformation: the role of the missing middle', World Development, 63, 43-58.

Cobbinah, P. B. and Aboagye, H. N. (2017) 'A Ghanaian twist to urban sprawl', Land Use Policy, 6I, 23I-24I. 
Cohen, B. (2006) 'Urban growth in developing countries: a review of current trends and a caution regarding existing forecasts', Technology in Society, 28, 63-80.

Cross, S. and Kutengule, M. (200I) 'Decentralisation and rural livelihoods in Malawi' (LADDER Working Paper No. 4), https://www.gov.uk/dfid-research-outputs/decentralisation-and-rural-livelihoods-in-malawi (accessed ı December 2019).

Duminy, J., Odendaal, N. and Watson, V. (2014) 'Case study research in Africa: methodological dimensions', in J. Duminy, J. Andreasen, F. Lerise, N. Odendaal and V. Watson (eds), Planning and the Case Study Method in Africa: The Planner in Dirty Shoes, New York, Palgrave Macmillan, 2I-47.

Durand-Lasserve, A. (2003) Land for Housing the Poor in African Cities. Are Neo-customary Processes an Effective Alternative to Formal Systems?, Laboratoire SEDET Centre National de la Recherche Scientifique Université Denis Diderot.

Eggen, Ø. (201 I) 'Chiefs and everyday governance: parallel state organisations in Malawi', Journal of Southern African Studies, 37(2), 313-33I.

Englebert, P. (2002) 'Patterns and theories of traditional resurgence in tropical Africa', Mondes en développement, $\mathrm{I} 8 \mathrm{8}(2), 5^{\mathrm{I}-64}$.

Fold, N. and Tacoli, C. (2010) 'Agricultural frontier settlements: markets, livelihood diversification and small town development', in J. Agergaard, K. V. Gough and N. Fold (eds), Rural-urban Dynamics: Livelihoods, Mobility and Markets in African and Asian Frontiers, London, Routledge, 90-98.

Forester, P. G. (1994) 'Culture, nationalism and the invention of tradition in Malawi', fournal of Modern African Affairs, 32(3), 477-497.

Fox, S. (2012) 'Urbanization as a global historical process: theory and evidence from sub-Saharan Africa', Population and Development Review, 38(2), 285-310.

Fox, S. (2017) 'Mortality, migration, and rural-urban transformation in sub-Saharan Africa's urban transition', Journal of Demographic Economics, 83, I3-30.

Fuseini, I. and Kemp, J. (2015) 'A review of spatial planning in Ghana's socio-economic development trajectory: a sustainable development perspective', Land Use Policy, 47, 309-320.

Goodfellow, T. (2013) 'Planning and development regulation amid rapid urban growth: explaining divergent trajectories in Africa', Geoforum, 48, 83-93.

Gutkind, P. C. W. (I966) 'African urban chiefs: agents of stability or change in African urban life?', Anthropologica, 8(2), 249-268.

Haggblade, S., Hazell, P. and Reardon, T. (2010) 'The rural non-farm economy: prospects for growth and poverty reduction', World Development, 38(Io), I429-I44I.

Hardoy, J. E. and Satterthwaite, D. (I986) Small and Intermediate Urban Centres: Their Role in National and Regional Development in The Third World, London, IIED.

Home, R. (2010) Of Planting and Planning: The Making of British Colonial Cities, Abingdon, Routledge.

Kalinga, O. J. M. (I979) 'Trade, the Kyungus, and the emergence of the Ngonde Kingdom of Malawi', The International Journal of African Historical Studies, I2(I), I7-39.

Kalinga, O. J. M. (I980) 'The Karonga war: commercial rivalry and politics of survival', The Journal of African History, 21(2), 209-218. 
Kalinga, O. J. M. (1998) 'The production of history in Malawi in the Ig6os: the legacy of Sir Harry Johnston, the influence of the society of Malawi and the role of Dr. Kamuzu Banda and his Malawi Congress Party', African Affairs, 97, 523-549.

Kalipeni, E. (1997) 'Contained urban growth in post-independence Malawi', East African Geographical Review, I9(2), 49-66.

Kishindo, P. (2004) 'Customary land tenure and the new land policy in Malawi', fournal of Contemporary African Studies, 22(2), 213-225.

Knudsen, M. H. (2010) 'Small town development in the Ghanaian cocoa frontier', in Agergaard et al. (eds), 43-6o.

Knudsen, M. H. and Agergaard, J. (2015) 'Ghana's cocoa frontier in transition: the role of migration and livelihood diversification', Geografiska Annaler, Series B: Human Geography, 97(4), 325-342.

Larsen, M. N. and Birch-Thomsen, T. (2015) 'The role of credit facilities and investment practices in rural Tanzania: a comparative study of Igowole and Ilula emerging urban centres', Fournal of Eastern African Studies, 9(I), 55-73.

Lazaro, E., Agergaard, J., Larsen, M. N., Makindara, J. and Birch-Thomsen, T. (2019) 'Urbanisation in rural regions: the emergence of urban centres in Tanzania', The European fournal of Development Research, 3I(I), 72-94.

Leduka, R. C. (2006) 'Chiefs, civil servants and the city council: state-society relations in evolving land delivery processes in Maseru, Lesotho', International Development Planning Review, 28(2), I8I-208.

Liuma, F. (1998) Land Administration, Paper prepared for the Presidential Commission on Land Policy Reform.

Mabogunje, A. L. (I990) 'Urban planning and the post-colonial state in Africa: a research overview', African Studies Review, 33(2), I2 I-203.

Mamdani, M. (1996) Citizen and Subject: Contemporary Africa and The Legacy of Late Colonialism, Princeton, NJ, Princeton University Press.

Manda, M. A. Z. (2013) 'Situation of urbanisation in Malawi report', Lilongwe, Malawi, Government of Malawi.

Manda, M. A. Z. (2014) 'Where there is no local government: addressing disaster risk reduction in a small town in Malawi', Environment E Urbanization, 26(2), 586-599.

Manda, M. A. Z. and Wanda, E. (2017) 'Understanding the nature and scale of risks in Karonga, Malawi', Environment $\mathcal{E}$ Urbanization, 29(I), I5-32.

Manda, M. A. Z., Kamlomo, D, Mphande, C, Wanda, E, Msiska, O, Kaunda, J, Kushe, J. (2016) Karonga Town: Growth and Risk Profile (Working Paper No. 4), Malawi, Urban ARK.

McCracken, J. (2003) 'Conservation and resistance in colonial Malawi: the 'dead north' revisited', in W. Beinart and J. McGregor (eds), Social History and African Environments, Oxford, James Currey.

McFarlane, C. and Robinson, J. (2012) 'Introduction: experiments in comparative urbanism', Urban Geography, 33(6), 765-773.

McGranahan, G. and Satterthwaite, D. (2014) 'Urbanisation concepts and trends' (Working Paper), London, IIED.

McGregor, D., Simon, D. and Thompson, D. (2006) The Peri-urban Interface: Approaches to Sustainable Natural and Human Resource Use, London, Earthscan. 
Ministry of Lands and Housing (2013) Karonga Urban Structure Plan, Lilongwe, Malawi, Government of Malawi, Physical Planning Department.

Ministry of Lands, Housing and Urban Development (2015) 'Malawi habitat III report', Lilongwe, Malawi, Government of Malawi.

Montgomery, M. R. (2008) 'The urban transformation of the developing world', Science, 3I9(5864), 76I-764.

Moriconi-Ebrard, F., Harre, D. and Heinrigs, P. (2016) Urbanization Dynamics in West Africa 1950-20I0: Africapolis I, 2015 Update, Paris, OECD Publishing.

Msisha, R. (1998) Land Law in Malawi, Paper prepared for the Presidential Commission on Land Policy Reform.

Myers, G. (2011) African Cities: Alternative Visions of Urban Theory and Practice, New York, Zed Books.

Njoh, A. J. (2009) 'Urban planning as a tool of power and social control in colonial Africa', Planning Perspectives, 24(3), 30 I-3 17 .

Nkurunziza, E. (2007) 'Informal mechanisms for accessing and securing urban land rights: the case of Kampala, Uganda', Environment \& Urbanization, I9(2), 509-526.

NSO (National Statistical Office) (2008) 2008 Population and Housing Census, Zomba, NSO.

NSO (National Statistical Office) (2018) 2018 Malawi Population and Housing Census: Main Report, Zomba, NSO.

O’Neil, T. and Cammack, D. with Kanyongolo, E., Mkandawire, M. W., Mwalyambwire, T., Welham, B. and Wild, L. (2014) 'Fragmented governance and local service delivery in Malawi' (Report), London, ODI.

Onokerhoraye, G. (I975) 'Urbanism as an organ of traditional African civilization: the example of Benin, Nigeria', Civilisations, 25(3/4), 294-306.

Parnell, S. and Robinson, J. (2012) '(Re)theorizing cities from the global South: looking beyond neoliberalism', Urban Geography, 33(4), 593-6r7.

Pedersen, P. O. (I997) Small African Towns: Between Rural Networks and Urban Hierarchies, Aldershot, Ashgate.

Pieterse, E. (2008) City Futures: Confronting the Crisis of Urban Development, London, Zed Books.

Pieterse, E. (201 I) 'Grasping the unknowable: coming to grips with African urbanisms', Social Dynamics, 37(I), 5-23.

Pieterse, E. and Parnell, S. (2014) 'Africa's urban revolution in context', in S. Parnell and E. Pieterse (eds), Africa's Urban Revolution, New York, Zed Books, I-I7.

Potts, D. (1985) 'Capital relocation in Africa: the case of Lilongwe in Malawi', The Geographical fournal, $\mathrm{I} 5 \mathrm{I}(2), \mathrm{I} 82-\mathrm{I} 96$.

Potts, D. (2012) Whatever Happened to Africa's Rapid Urbanisation? London, Africa Research Institute.

Power, J. (2010) Political Culture and Nationalism in Malawi: Building Kwacha, Rochester, University of Rochester Press.

Rakodi, C. (1997) 'Global forces, urban change, and urban management in Africa', in C. Rakodi (ed.), The Urban Challenge in Africa: Growth and Management of its Large Cities, New York, United Nations University, I7-73. 
Rakodi, C. (2006) 'State-society relations in land delivery processes in five African cities', International Development Planning Review, 28(2), 263-285.

Redfield, R. and Singer, M. (1954) 'The cultural role of cities', Economic Development and Cultural Change, 3, 53-73.

Refstie, H. and Brun, C. (2016) 'Voicing noise: political agency and the trialectics of participation in urban Malawi', Geoforum, 74, I36-I46.

Refstie, H. and Millstein, M. (2019) 'Does participatory planning promise too much? Global discourses and the glass ceiling of participation in urban Malawi', Planning Theory and Practice, 20(2), 24I-257.

Rhodes, R. A. W. (1997) Understanding Governance: Policy Networks, Governance, Reflexivity and Accountability, Maidenhead, Open University Press.

Robinson, J. (2002) 'Global and world cities: a view from off the map', International fournal of Urban and Regional Research, 26, 53 ${ }^{-}-554$.

Robinson, J. (2006) Ordinary Cities: Between Modernisty and Development, New York, Routledge.

Robinson, J. (201 I) 'Cities in a world of cities: the comparative gesture', International fournal of Urban and Regional Research, 53(I), I-23.

Robinson, J. (2015) 'Comparative urbanism: new geographies and cultures of theorizing the urban', International Journal of Urban and Regional Research, 40(I), I87-I99.

Rondinelli, D. A. (I983) 'Dynamics of growth of secondary cities in developing countries', Geographical Review, 73(I), 42-57.

Rondinelli, D. and Ruddle, K. (1978) Urbanization and Rural Development: A Spatial Policy for Equitable Growth, New York, Praeger.

Satterthwaite, D. (2006) 'Outside the large cities: the demographic importance of small urban centres and large villages in Africa, Asia and Latin America' (Discussion Paper), London, IIED.

Satterthwaite, D. (2007) 'The transition to a predominantly urban world and its underpinnings' (Discussion Paper), London, IIED.

Satterthwaite, D. (2016) 'Background paper: small and intermediate urban centres in sub-Saharan Africa' (Working Paper No. 6), London, IIED, Urban ARK.

Satterthwaite, D. and Tacoli, C. (2003) 'The urban part of rural development: the role of small and intermediate urban centres in rural and regional development and poverty reduction' (Working Paper No. 9), London, IIED.

Segal, E. S. (1985) 'Projections of internal migration in Malawi: implications for development', The Fournal of Modern African Studies, 23(2), 315-329.

Siiba, A., Adams, E. A. and Cobbinah, P. B. (2018) 'Chieftaincy and sustainable urban land use planning in Yendi, Ghana: towards congruence', Cities, 73, 96-IO5.

Simon, D. (1992) 'Conceptualizing small towns in African development', in Baker and Pedersen (eds), 29-49.

Simon, D. (1997) 'Urbanization, globalization, and economic crisis in Africa', in Rakodi (ed.), 74-108.

Simon, D., McGregor, D. and Nsiah-Gyabaah, K. (2004) 'The changing urban-rural interface of African cities: definitional issues and an application to Kumasi, Ghana', Environment and Urbanization, I6(2), 235-248. 
Smit, W. (2018) 'Urban governance in Africa: an overview', International Development Policy, Io, $55^{-77}$.

Smit, W. and Pieterse, E. (2014) 'Decentralisation and institutional reconfiguration in urban Africa', in Parnell and Pieterse (eds), I48-i66.

Steel, G., Birch-Thomsen, T., Cottyn, I., Lazaro, E. A., Mainet, H., Mishili, F. J., and van Lindert, P. (2019) 'Multi-activity, multi-locality and small-town development in Cameroon, Ghana, Rwanda and Tanzania', The European Fournal of Development Research, 3I(I), I2-33.

Stoker, G. (I998) 'Governance as theory: five propositions', International Social Sciences fournal, I2(I), I48-I66.

Stren, R. E. and White, R. R. (I989) African Cities in Crisis: Managing Rapid Urban Growth, Boulder, $\mathrm{CO}$, Westview Press.

Tacoli, C., McGranahan, G. and Satterthwaite, D. (2015) 'Urbanisation, rural-urban migration and urban poverty' (Working Paper), London, IIED.

Tieleman, J. and Uitermark, J. (2019) 'Chiefs in the city: traditional authority in the modern state', Sociology, 53(4), 707-723.

Ubink, J. (2007) 'Traditional authority revisited: popular perceptions of chiefs and chieftaincy in peri-urban kumasi, Ghana', Journal of Legal Pluralism and Unofficial Law, 39(55), I23-I6I.

Ubink, J. M. (2008a) In the Land of the Chiefs: Customary Law, Land Conflics, and the Role of the State in Peri-urban Ghana, Amsterdam, Leiden University Press.

Ubink, J. (2008b) Traditional Authorities in Africa Resurgence in an Era of Democratisation, Leiden, Leiden University Press.

Ubink, J. M. and Quan, J. F. (2008) 'How to combine tradition and modernity? Regulating customary land management in Ghana', Land Use Policy, 25(2), I98-213.

UN-Habitat (2010a) Malawi Urban Housing Sector Profile, UN-Habitat, Nairobi.

UN-Habitat (20I0b) State of African Cities 20I0: Governance, Inequality and Urban Land Markets, UN-Habitat, Nairobi.

UN-Habitat (2014) The State of African Cities 2014: Re-imagining Sustainable Urban Transitions, Nairobi.

UNDESA (United Nations Department of Economic and Social Affairs) (2018) World Urbanization Prospects: The 2018 Revision, https://population.un.org/wup/ (accessed 20 January 2020).

Watson, V. (2012) 'Planning and the "stubborn realities" of global South-east cities: some emerging ideas', Planning Theory, I2(I), 8I-Ioo.

Wekwete, K. H. (I995) 'Planning law in sub-Saharan Africa: a focus on the experiences in Southern and Eastern Africa', Habitat International, I9(I), I3-28.

World Bank (2016) Malawi Urbanization Review: Leveraging Urbanization for National Growth and Development, Washington DG, World Bank.

Yeboah, E. and Obeng-Odoom, F. (2010) "We are not the only ones to blame": district assemblies' perspectives on the state of planning in Ghana', Commonwealth fournal of Local Governance, 1996, 78-98.

Yeboah, E. and Shaw, D. (2013) 'Customary land tenure practices in Ghana: examining the relationship with land-use planning delivery’, International Development Planning Review, 35(I), $2 \mathrm{I}-39$. 